\title{
Survival of innovative technology startups: the case of the technet regional corporate accelerator
}

\author{
Olga Andreeva ${ }^{1 *}$, Vladimir Postnikov ${ }^{2}$ \\ Perm National Research Polytechnic University, 29, Komsomolsky prospect, Perm, 614990, Russia
}

\begin{abstract}
The article discusses the question of how the participation of technology startups in the corporate accelerator affects their survival. We compare the activity of technological projects over 3 years according to the Startup Barometer and the results of the work of the corporate accelerator "Big Exploration" for 2018-2020. The survival rate of accelerator projects interacting with the UEC corporation is by $20 \%$ higher than that of projects developed independently. This research was partially supported by the Ministry of Education and Science of the Russian Federation to Perm National Research Polytechnic University (topic No. FSNM-2020-0026).
\end{abstract}

\section{Introduction}

Any startup has similar problems at the initial stage of development. Such problems are difficulties in finding sources of financing for the project, conducting market research, determining a group of consumers or a market place. One of the effective tools for the startups development, actively used in the last 15 years, is an accelerator. The accelerator is a program that ensures the accelerated development and implementation of innovative projects that are in the early stages of development through the implementation of intensive mentoring, investment support for projects. In recent years, a new type of corporate accelerators has been actively developing, which create opportunities for small startups to interact with large industrial customers.

Studies of world experience in works of Alänge S., Steiber A. (2018), Becker B., Gassmann O. (2006), Birley S. (2005), Pauwels C., Clarysse B. (2016), Kamenskikh M. (2018) presented the problems associated with the development of new technologies and products. It is effective to use gas pedals as an institution of networking of startups, industrial enterprises, universities, authorities and external institutions.

Corporate accelerators have gained active development in recent times in the world and in Russia. The corporate accelerator is a mechanism for achieving the company's goals, providing accelerated implementation, development of startups that have passed the test of the "viability" of projects (Kamensky M.A. (2018), Postnikov V.P., Gulyaeva M.M. (2019). The corporate accelerator is considered as a way to stimulate industrial innovations with the help of startups. Within the framework of the corporate accelerator, educational events are held; company resources and mentoring support are provided in various areas.
The empirical study presented in this paper aims to statistically assess the survival outcomes of startups. The development of technology startups in Russia can be considered an element of the national strategy since 2015, when the documents and formats defining the "Platform of the National Technology Initiative" were finally determined. The goal of this Platform was to create conditions for the development of a national innovation ecosystem, high-tech products. Officially, the Platform began work in 2018, after Dmitry Medvedev had signed a decree, so the analysis of startups has been also performed starting from this period.

The study examines the results of the startups development that passed through the Great Exploration accelerator and worked as part of the accelerator with large companies, such as the United Engine Corporation in the format of a corporate accelerator.

The purpose of the study is to determine the dynamics of the corporate accelerator startups survival rate, as well as to assess the degree of influence of large industrial partners on the formation and development of startups.

The empirical basis of the study was the projects of the accelerator "Great Exploration" for the period of 2018-2020. The main focus of the study is on the analysis of projects of the TechNet regional corporate accelerator, which includes projects in the field of advanced production technologies, digital design and part modeling, facilities, technologies, systems, industries, additive technologies, development of new materials and coatings, industrial robotics, sensors and photonics. The key industrial partners and industry experts in the direction of the TechNet accelerator "Great Exploration" are traditionally the enterprises of the aerospace cluster of the Perm Territory (Andreeva O., Postnikov V. (2017), in particular, the enterprises of the United Engine Corporation. The experts, who are representatives of the UEC, formed a group of projects, 
which were further developed with the help of the corporate accelerator and became the object of monitoring.

\section{Literature Review}

Factors contributing to the development and strengthening in the market of technological startups are a separate subject of discussion and research in different countries. World statistics show that no more than $1 \%$ of innovative developments reach the stage of real sales. The rest of the projects stop developing or close down, not having found enough consumers. The reasons may be both low adaptation of product characteristics to consumers demands and difficulties in product and team managing, insufficient knowledge and skills in working with the market, planning skills. Evaluating the factors that allow a technology team to develop its project is of interest to various groups of researchers who study the relationship between certain team actions and the result. Caliendo M., Goethner M., Weißenberger M. (2020) describes a series of studies on the reasons that determine entrepreneurial persistence. According to their findings, startup survival correlates quite strongly with both the individual characteristics (human capital and personality) of the founder and the business characteristics of the founder. Eliakis S., Kotsopoulos D., Karagiannakiand A., Pramatari K. (2020) also consider the personal aspects of technology startups founders and employees, focusing on the organizational performance of the entrepreneurial team.

A large-scale quantitative study by Goraczkowska J. (2020) formulates the hypothesis that a startup's participation in a technological incubator or university business incubator contributes to its higher probability of conducting $\mathrm{R} \& \mathrm{D}$ and implementing product and technological innovations. This is confirmed by the author through a study in which the sample includes 1,058 industrial enterprises located in two Polish regions.

Often researchers note that the stimulating factor for the emergence of innovation for new enterprises is the interaction with corporate accelerators. Crișan, E.L., Salanţă, I.I., Beleiu, I.N., Bordean, O.N., Bunduchi, R. (2019) monitored papers that identified mechanisms explaining how accelerators work in general and what role they play in supporting entrepreneurship and innovation. Key elements of innovation development included: validating ideas and products; providing product development and model learning; providing support to increase startup market access and growth; and supporting innovation.

Urbaniec, M., Żur, A. (2020) conducted a study confirming that corporate accelerators are a source of innovation. Participation in such accelerators can be used to develop entrepreneurial market logic. The authors use qualitative methods to explore the motivations behind interactions of corporations with startups and identify the corporate advantages and disadvantages of such a business model.
A local study on corporate startup support programs was conducted by T. Gutmann, D.Kanbach, S.Seltman, (2019). In this in-depth study, with an inductive research design, the subject was the SAP Industry 4.0 startup program. The authors used qualitative methods to study a recently established program of corporate accelerators at one of the world's largest enterprise software companies. The study resulted in a list of benefits for startups participating in corporate acceleration programs related to rapid time-to-market, accelerated sales, and knowledge development.

S. Kurpjuweit, S. M. Wagner (2020) note that collaboration between established companies and startups is increasingly seen as a component of the corporate strategy. N. Del Sartoa, D. A. Isabelleb, A.Di Mini (2020) examine the relationship between participation in an accelerator program and startup survival. The authors analyzed 38 startups from five Italian accelerators and compared them to a control group of 38 Italian startups developing independently. Using qualitative comparative analysis (using fuzzy sets), the authors show that participation in accelerator programs by itself does not affect company survival.

The effectiveness of corporate accelerators is also studied in detail by Russian researchers. A. Popov (2020), examining the structure of corporate demand for high-tech startup solutions, finds that if a startup's business model is focused on large business as its main customer segment, such startups should be ready to have their own resources not only for the deal-making process, but also for technical finalization of their own solution based on the corporation's recommendations. Yu.N. Alexandrin and Yu.V. Gorbova (2020) analyze the specifics of the development of different of accelerators (state, corporate, private and university) in Russia. They note that Russian accelerators are not only developing similar to global trends, but also have better business models compared to other countries. In addition, it was found that corporate accelerators are the most actively developing format at the moment.

The survival rate of startups in different industries is assessed mainly by practices (investors, experts and analysts of various funds). For example, Tsaplin E. and Kosova O. (2019) evaluate the usefulness of accelerators for IT companies through case analysis. They found that participation in an accelerator develops entrepreneurial qualities, helps to avoid some mistakes, but does not give guarantees of survival in the market.

Stayton J., Mangematin V. (2019) look at the mechanisms by which accelerators help new technology ventures minimize start-up time. They highlight this factor (rapid product launch) as key to the survival of a startup. The authors also describe acceleration mechanisms, among which are the provision of such types of resources as offices, the opportunity to develop $\mathrm{R} \& \mathrm{D}$, a network of expertise and industry contacts, special regimes and funding sources, and the provision of intensive mentoring. 


\section{Design and Methods}

A comparative data analysis was done to assess the dynamics of the technological startups development that participated in the Great Exploration accelerator. The first stage aggregated information on technological entrepreneurship in Russia, collected by the StartupBarometer project.

The second stage monitored the lifecycle of startups that participated in Great Exploration in 2018-20. A selection funnel was constructed, which all projects that applied undergo. Then 62 formalized interviews were then conducted with projects that applied to the TechNet track. Of these, 39 projects underwent general acceleration, and 23 participated in the corporate accelerator of PJSC UEC (United Engine Corporation). The interviews included four sets of questions about how the project has developed over the years. This data was analyzed in terms of assessing project survival and determining the impact on their current state of interaction with UEC as a strong industrial partner.

\section{Results}

The first stage of the study involved the analysis of startup data collected by the StartupBarometer project. The data collection was done by questionnaire survey of technology startup participants from 2018 to 2020. Over three years, there has been an increase both in the composition of participants and in the variety of technological areas represented by participants (Table 1).

The method of data collection remained unchanged. All these years it has been a survey, including questions to make a portrait of the startup founder, access the team, the level of business development, ways to sell, and sufficiency of financing.

Each year the questionnaire is supplemented with useful questions, but the main questions remain unchanged. The table shows that the data grouping system has changed somewhat over the course of the study. The 2019 survey showed that almost $80 \%$ of respondents are interested in working with corporations. Entrepreneurs meet representatives of large companies at industry events (27\%) and get contacts through networking $(25 \%) .15 \%$ of founders participate in competitions and corporate accelerators for this purpose.

In 2019 corporations were seen as a strategic partner by $41 \%$, as an investor by $12 \%$, as a client by $37 \%$. According to the results of the survey in 2020, it was found that $80 \%$ of entrepreneurs (the same as the year before) are already working or are considering working with corporations. At the same time, $68 \%$ of startups say that corporations currently do not help to develop their businesses. When clarifying the degree of interest of corporations in working with startups, $69 \%$ of founders accessed it as average or below average. And $11 \%$ believe that corporations have absolutely no interest in such cooperation.
The age of startups as of the date of the survey was also accessed. In 2018, the average age was 3 years. In 2019, the age distribution was as follows:

-1 year - $20 \%$;

-2 years $-14 \%$;

-3 years $-13 \%$;

- more than 4 years $-53 \%$.

In 2020 , there was a slight increase in proportion in each age segment:

-1 year - $28 \%$;

-2 years $-18 \%$;

-3 years $-15 \%$;

- more than 4 years $-39 \%$.

A review of the projects age shows that about half of them have remained active for four years or more. Data from 2019 highlighted projects older than 5 years, their share was $15 \%$.

The results of the first stage are interesting because they show a cross-section of the situation in the same time interval as the analysis of the Great Exploration projects. This does not mean that startups older than 3-4 years have high financial indicators; rather it shows that "physical survival" can be estimated with a coefficient of about 0.4 .

The second phase of the study is a study of the development of projects that were selected by the Great Exploration experts for acceleration and passed the demo day.

To understand the scale of involvement of technology projects in acceleration over three years, we consider the project selection funnel presented in Table 2. The indicators in Table 2 show a 3.1-fold increase in the number of applications to the accelerator over 3 years, while the number of applications in the TechNet direction has increased 2.5 times over 3 years. There has also been a $46,4 \%$ growth in the number of projects selected and passed the acceleration program over 3 years, including a $44,4 \%$ growth in the TechNet direction. The outpacing growth in the number of incoming applications leads to increased competition among projects for entry into the accelerator.

While in $201837.3 \%$ of projects were selected for the acceleration program, in 2019 - already $25.0 \%$, and in $2020-17.7 \%$. In the TechNet direction, $50.0 \%$ of applications were selected for the acceleration program in $2018,38.3 \%$ were in $2019,29.2 \%$ were in 2020 . Thus, the competition to get projects into the acceleration program has almost doubled. It is possible to replace the higher percentage of projects involved in acceleration in the TechNet direction compared to other areas, which indicates a higher quality and prospects of projects aimed at working with corporate partners.

In order to assess the survival rate of projects, such characteristics of startups as their existence in 2021, their getting additional funding and active cooperation with industrial partners were considered (see Table 3). 
Table 1. Characteristics of StartupBarometer participants

\begin{tabular}{|c|c|l|l|}
\hline Year & $\begin{array}{c}\text { Number of } \\
\text { respondents }\end{array}$ & \multicolumn{1}{|c|}{ Main directions } & \multicolumn{1}{|c|}{ Structure (development stage) } \\
\hline 2018 & 300 & Marketplaces, FinTech, SaaS. & $\begin{array}{l}9 \% \text { - idea } \\
49 \% \text { - prototype and MVP } \\
42 \% \text { - sales and growth }\end{array}$ \\
\hline 2019 & 500 & $\begin{array}{l}\text { Produsts for business, AI-technologies, BigData, EdTech, } \\
\text { IoT, Marketplaces. }\end{array}$ & $\begin{array}{l}14 \% \text { - idea } \\
54 \% \text { - prototype and MVP } \\
32 \% \text { - sales and growth }\end{array}$ \\
\hline 2020 & 620 & $\begin{array}{l}\text { SaaS-projects, AI, EdTech, Hardware, Software, BioTech, } \\
\text { Auto\&Transportation, MedTech, Marketplace, Robotics }\end{array}$ & $\begin{array}{l}5 \% \text { - idea } \\
51 \% \text { - prototype and MVP44\% - } \\
\text { sales and growth }\end{array}$ \\
\hline
\end{tabular}

Authors on the basis of StartupBarometer

Table 2. The selection funnel for technological projects of the Great Exploration accelerator in 2018-2020

\begin{tabular}{|c|l|c|c|c|c|c|c|c|c|}
\hline \multirow{2}{*}{$\begin{array}{c}\mathrm{N} \\
0\end{array}$} & \multicolumn{1}{|c|}{ Index } & \multicolumn{2}{|c|}{2018} & \multicolumn{2}{|c|}{2019} & \multicolumn{2}{c|}{2020} & \multicolumn{2}{c|}{$2018-2020$} \\
\cline { 2 - 9 } & Total & $\begin{array}{c}\text { incl. } \\
\text { TechNet }\end{array}$ & Total & $\begin{array}{c}\text { incl. } \\
\text { TechNet }\end{array}$ & Total & $\begin{array}{c}\text { incl. } \\
\text { TechNet }\end{array}$ & $\begin{array}{c}\text { Total } \\
\text { incl. } \\
\text { TechNet }\end{array}$ \\
\hline 1 & $\begin{array}{l}\text { Number of applications } \\
\text { received, un }\end{array}$ & 150 & 36 & 296 & 47 & 462 & 89 & 908 & 172 \\
\hline 2 & $\begin{array}{l}\text { Number of projects admitted } \\
\text { prior to selection, un }\end{array}$ & 134 & 29 & 186 & 37 & 341 & 58 & 661 & 124 \\
\hline 3 & $\begin{array}{l}\text { Percentage of projects } \\
\text { admitted to selection, } \%\end{array}$ & $89.3 \%$ & $80.6 \%$ & $62.8 \%$ & $72.3 \%$ & $73.8 \%$ & $65.2 \%$ & $72.8 \%$ & $72.1 \%$ \\
\hline 4 & $\begin{array}{l}\text { Number of projects selected } \\
\text { for acceleration, un }\end{array}$ & 56 & 18 & 74 & 18 & 82 & 26 & 212 & 62 \\
\hline 5 & $\begin{array}{l}\text { Percentage of projects } \\
\text { selected for acceleration, } \%\end{array}$ & $37.3 \%$ & $50.0 \%$ & $25.0 \%$ & $38.3 \%$ & $17.7 \%$ & $29.2 \%$ & $23.3 \%$ & $36.0 \%$ \\
\hline 6 & $\begin{array}{l}\text { Number of projects on the } \\
\text { demo day, un }\end{array}$ & 42 & 10 & 40 & 9 & 64 & 18 & 146 & 37 \\
\hline 7 & $\begin{array}{l}\text { Percentage of projects } \\
\text { presented on demo day, } \%\end{array}$ & $28.0 \%$ & $27.8 \%$ & $13.5 \%$ & $19.1 \%$ & $13.9 \%$ & $20.2 \%$ & $16.1 \%$ & $21.5 \%$ \\
\hline
\end{tabular}

Authors on the basis of the Great Exploration

Table 3. Analysis of the survival rate of Great Exploration accelerator startups for 2021

\begin{tabular}{|c|c|c|c|c|c|c|c|c|c|c|c|c|c|}
\hline \multirow{2}{*}{$\begin{array}{l}\mathrm{N} \\
\mathrm{o}\end{array}$} & \multirow[t]{2}{*}{ Index } & \multicolumn{3}{|c|}{2018} & \multicolumn{3}{|c|}{2019} & \multicolumn{3}{|c|}{2020} & \multicolumn{3}{|c|}{$2018-2020$} \\
\hline & & $\begin{array}{l}\text { Total } \\
\text { Tech } \\
\text { Net }\end{array}$ & $\begin{array}{l}\text { With } \\
\text { out } \\
\text { UEC }\end{array}$ & UEC & $\begin{array}{l}\text { Total } \\
\text { Tech } \\
\text { Net }\end{array}$ & $\begin{array}{l}\text { With } \\
\text { out } \\
\text { UEC }\end{array}$ & UEC & $\begin{array}{l}\text { Total } \\
\text { Tech } \\
\text { Net }\end{array}$ & $\begin{array}{l}\text { With } \\
\text { out } \\
\text { UEC }\end{array}$ & UEC & $\begin{array}{l}\text { Total } \\
\text { Tech } \\
\text { Net }\end{array}$ & $\begin{array}{l}\text { With } \\
\text { out } \\
\text { UEC }\end{array}$ & UEC \\
\hline 1 & $\begin{array}{l}\text { Number of projects that have } \\
\text { undergone acceleration, un }\end{array}$ & 18 & 10 & 8 & 18 & 12 & 6 & 26 & 17 & 9 & 62 & 39 & 23 \\
\hline 2 & Relevant projects for 2021 , un & 8 & 3 & 5 & 15 & 9 & 6 & 20 & 12 & 8 & 43 & 24 & 19 \\
\hline 3 & $\begin{array}{l}\text { Percent of survival startups, } \\
\%\end{array}$ & $\begin{array}{c}44.0 \\
\%\end{array}$ & $\begin{array}{c}30.0 \\
\%\end{array}$ & $\begin{array}{c}62.5 \\
\%\end{array}$ & $\begin{array}{c}83.3 \\
\%\end{array}$ & $\begin{array}{c}75.0 \\
\%\end{array}$ & $\begin{array}{l}100 . \\
0 \%\end{array}$ & $\begin{array}{c}76.9 \\
\%\end{array}$ & $\begin{array}{c}70.6 \\
\%\end{array}$ & $\begin{array}{c}88.9 \\
\%\end{array}$ & $\begin{array}{c}69.4 \\
\%\end{array}$ & $\begin{array}{c}61.5 \\
\%\end{array}$ & $\begin{array}{c}82.6 \\
\%\end{array}$ \\
\hline 4 & $\begin{array}{l}\text { Projects that received grant } \\
\text { funding, un }\end{array}$ & 6 & 1 & 5 & 13 & 8 & 5 & 7 & 5 & 2 & 26 & 14 & 12 \\
\hline 5 & $\begin{array}{l}\text { Percentage of projects funded } \\
\text { against accelerated projects, } \%\end{array}$ & $\begin{array}{c}33.3 \\
\%\end{array}$ & $\begin{array}{c}10.0 \\
\%\end{array}$ & $\begin{array}{c}62.5 \\
\%\end{array}$ & $\begin{array}{c}88.9 \\
\%\end{array}$ & $\begin{array}{c}66.7 \\
\%\end{array}$ & $\begin{array}{c}83.3 \\
\%\end{array}$ & $\begin{array}{c}26.9 \\
\%\end{array}$ & $\begin{array}{c}29.4 \\
\%\end{array}$ & $\begin{array}{c}22.2 \\
\%\end{array}$ & $\begin{array}{c}41.9 \\
\%\end{array}$ & $\begin{array}{c}35.9 \\
\%\end{array}$ & $\begin{array}{c}52.2 \\
\%\end{array}$ \\
\hline 6 & $\begin{array}{l}\text { Projects working with } \\
\text { industrial partners, un }\end{array}$ & 6 & 1 & 5 & 8 & 5 & 3 & 16 & 10 & 6 & 30 & 16 & 14 \\
\hline 7 & $\begin{array}{l}\text { Share of projects against } \\
\text { projects that have undergone } \\
\text { acceleration, } \%\end{array}$ & $\begin{array}{c}33.3 \\
\%\end{array}$ & $\begin{array}{c}10.0 \\
\%\end{array}$ & $\begin{array}{c}62.5 \\
\%\end{array}$ & $\begin{array}{c}44.4 \\
\%\end{array}$ & $\begin{array}{c}41.7 \\
\%\end{array}$ & $\begin{array}{c}50.0 \\
\%\end{array}$ & $\begin{array}{c}61.5 \\
\%\end{array}$ & $\begin{array}{c}58.8 \\
\%\end{array}$ & $\begin{array}{c}66.7 \\
\%\end{array}$ & $\begin{array}{c}48.4 \\
\%\end{array}$ & $\begin{array}{c}41.0 \\
\%\end{array}$ & $\begin{array}{c}60.9 \\
\%\end{array}$ \\
\hline
\end{tabular}

Authors on the basis of the Great Exploration 
The funnel of projects through the stages of the accelerator is shown in Fig. 1.

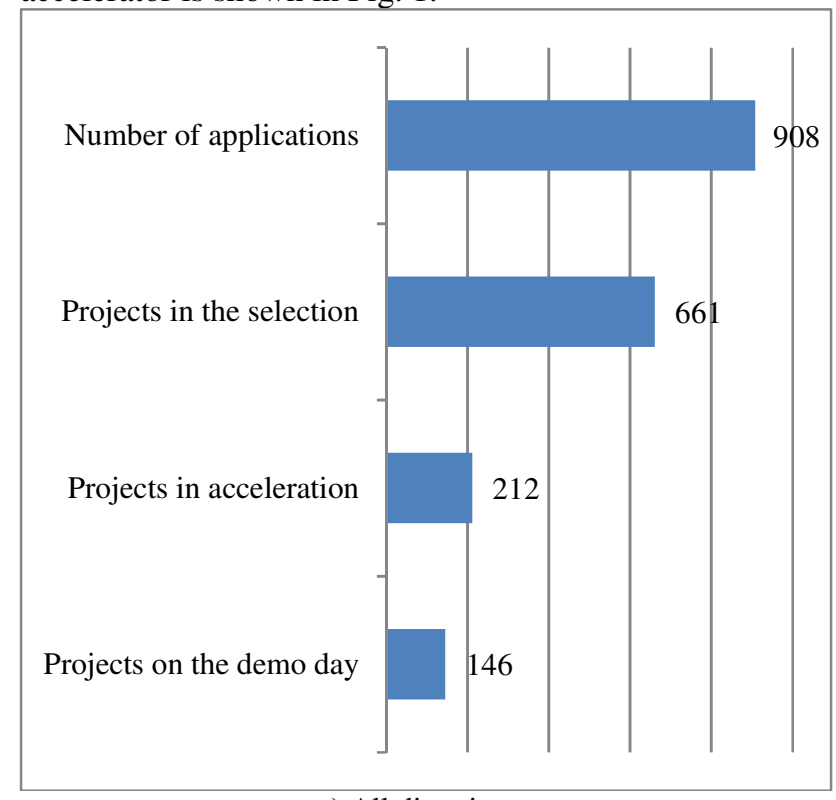

a) All directions

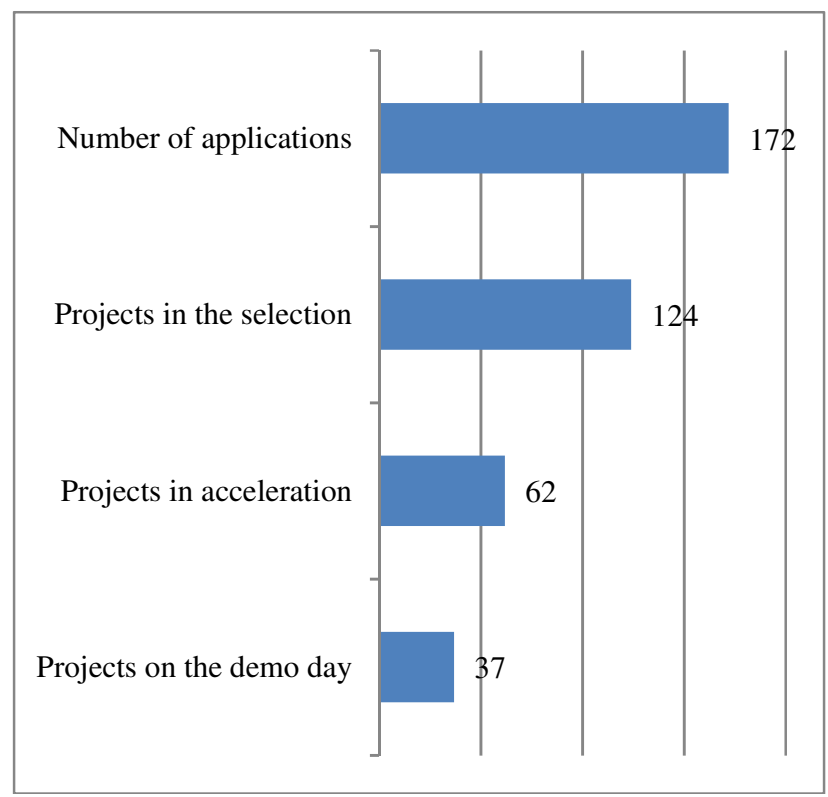

b) TechNet directions

Fig. 1. Funnel of projects of the accelerator of the Great Exploration for 2018-2020

According to Table 3, the survival rate of startups for 2021 out of those that passed the accelerator program in $2018-2020$ is $69.4 \%$. At the same time, the survival rate of startups that worked within the regional corporate accelerator of the United Engine Corporation (UEC) is higher than that of other startups (82.6\% versus $61.5 \%)$. This suggests a positive impact of corporate acceleration programs on startup survival relative to standard acceleration programs. Over the 2018-2020 period, only 4 projects (17.4\%) among projects working with UEC closed, and 19 projects continue to function, while among projects not interacting with the UEC, 15 projects (38.5\%) among projects not interacting with UEC closed, while 24 projects continue to function.

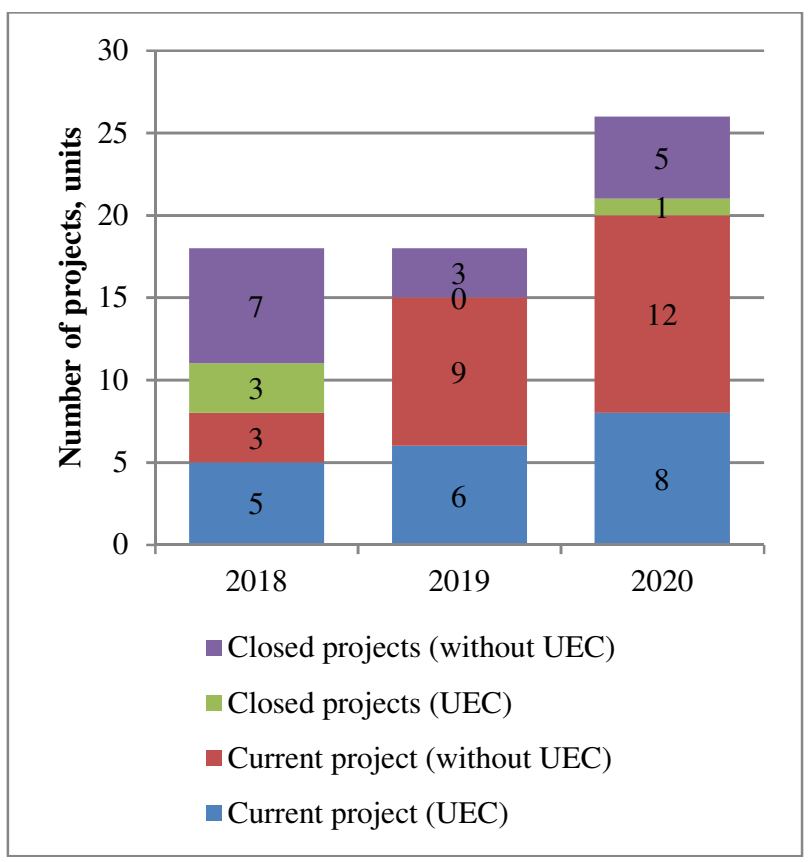

Fig. 2. Dynamics and structure of survival of projects in the TechNet direction of the Great Exploration accelerator for 2018-2020.

The analysis of projects that received grant funding also demonstrates the positive impact of corporate acceleration programs. The percentage of funding raised by startups that worked within the regional corporate accelerator programs is higher than that for the rest of the startups $(52.2 \%$ versus $35.9 \%)$. Interaction with the United Engine Corporation within the acceleration program had a positive impact on startups in getting their products to market $(30.4 \%$ versus $20.5 \%$ ) and on their interaction with industrial partners $(60.9 \%$ versus $41.0 \%)$.

Thus, the study showed that startups work with large industrial partners within the framework of corporate acceleration has a positive impact on development and survival in the future. First of all, this is associated with a higher quality of expertise on the part of partners at both the selection and acceleration stage. Working with an industrial partner allows the startup to gain quality industry expertise in technology and market, gain access to modern enterprise laboratories and the opportunity to conduct pilot tests, and subsequently to better form a value proposition to bring the product to market.

\section{Conclusions}

The issues of startup development, factors of their growth and survival, and conditions stimulating their success are of interest to both theoretical researchers and experts, and investors. Crișan, E.L. et al. (2019) reviewed 98 works over 15 years (2004 to 2019) on the impact of accelerators on startup development that identifies mechanisms to support innovation through acceleration programs. StartupBarometer theoretical research and examination of data on startup characteristics and growth dynamics has provided direction for analyzing data on technological projects

\footnotetext{
* Corresponding author: oleandrperm@gmail.com
} 
participating in the Big Exploration accelerator. The research, conducted on projects of the Technet direction, provides an initial overview of the development dynamics of startups that have passed the regional corporate accelerator and interaction with large industrial partners within it.

A comparison of the results of technological startups that have undergone corporate acceleration in cooperation with UEC and without enterprises it allows us to draw the following conclusions:

- The corporation within the accelerator provides detailed technological expertise focused on its market or segment. Such expertise also guides the startup to the technological cycle that exists in this field.

- The project receives specialized industry feedback from the corporation, allowing it to focus specifically on this industry and production.

- Participation in a corporate accelerator does not accelerate the launch of the product on the market, due to a more detailed elaboration of requirements for the product, so that it can (if it is positively prepared) qualitatively integrate into the complex industry production chain.

Further research in this topic will focus on the impact of the development stage and startup portrait on survival and an analysis on the rest of the accelerator areas is envisioned.

\section{References}

1. S. Alänge, A. Steiber, Triple Helix, 8, (2018). https://doi.org/10.1186/s40604-018-0053-9

2. B. Becker, O. Gassmann, Journal of Technology Transfer, $31 \quad$ (2006). https://doi.org/10.1007/s10961-006-0008-6

3. S. Birley, Journal of Business Venturing, 1, (2005).

https://doi.org/10.1016/j.technovation.2015.09.00 3

4. C. Pauwels, B. Clarysse, Technovation, 50-51, (2016), https://doi.org/10.1016/j.technovation.2015.09.00 3

5. M. Kamenskikh Journal of Advanced Research in Law and Economics, 9, (2018). https://doi.org/10.14505//jarle.v9\%202(32).15

6. M.A. Kamenskikh Regional economics: theory and practice, 9, (2018). https://doi.org/10.24891/re.16.9.1725

7. M.M. Gulyaeva, V.P. Postnikov Regional economy: theory and practice, 4, (2019)

8. O.Y.Andreeva, V.P. Postnikov, Journal of Advanced Research in Law and Economics, 8, (2017). https://doi.org/10.14505/jarle.v8.8(30).02

9. M. Caliendo, M. Goethner, M. Weißenberger Journal of Small Business Management, 58, (2020), http://dx.doi.org/10.1080/00472778.2019.166653 2
10. S. Eliakis, D. Kotsopoulos, A. Karagiannakiand, K. Pramatari, Administrative Sciences. 10, (2020). https://doi.org/10.3390/admsci10030039

11. J. Goraczkowska Oeconomia Copernicana. 11, (2020). https://doi.org/10.24136/oc.2020.032

12. E. L. Crișan, I.I. Salanță, I. N. Beleiu, O. N. Bordean, R. Bunduchi, Journal of Technology Transfer, 46, (2019) https://doi.org/10.1007/s10961-019-09754-9

13. M. Urbaniec, A. Żur, (to be published) International Entrepreneurship and Management Journal, 2020. https://doi.org/10.1007/s11365020-00646-1

14. T. Gutmann, D. Kanbach, S. Seltman, Problems and Perspectives in Management, 17, (2019). http://dx.doi.org/10.21511/ppm.17(3).2019.18

15. S. Kurpjuweit, S. M. Wagner, California Management Review, 62, (2020) https://doi.org/10.1177\%2F0008125620914995

16. N. Del Sartoa, D. A. Isabelleb, A. Di Minina Technovation, 90-91, (2020) https://doi.org/10.1016/j.technovation.2019.1021 02

17. A.N. Popov Bulletin of REU named after G.V. Plekhanov. 17, (2020). http://dx.doi.org/10.21686/2413-2829-2020-4-3647

18. E.V. Tsaplin, O.A. Kosova, Information Society. 4-5, (2019).

19. J. Stayton, V. Mangematin, J TechnolTransf 44, (2019). https://doi.org/10.1007/s10961-017-96460

20. Yu.N. Alexandrin, Yu.V. Gorbova Economics: theory and practice. 3, (2020). http://econ.kubsu.ru/images/3_2020.pdf

21. H. Meyer, J. Sowah, UBI Global World Rankings of Business Incubators and Accelerators 20192020

http://dx.doi.org/10.13140/RG.2.2.16066.53441 